\title{
RESEARCH
}

Open Access

\section{Insights on the Russian HCV care cascade: minimal HCV treatment for HIV/HCV co-infected PWID in St. Petersburg}

Judith I. Tsui ${ }^{1 *}$, Stephen C. Ko ${ }^{2}$, Evgeny Krupitsky ${ }^{3,4}$, Dmitry Lioznov ${ }^{4,5}$, Christine E. Chaisson ${ }^{6}$, Natalia Gnatienko ${ }^{7}$ and Jeffrey H. Samet ${ }^{8,9}$

\begin{abstract}
Background: The human immunodeficiency virus (HIV) epidemic in Russia, driven by injection drug use, has seen a steady rise in the past two decades. Hepatitis $\mathrm{C}$ virus ( $\mathrm{HCV}$ ) infection is highly prevalent in people who inject drugs (PWID). The study aimed to describe the current frequency of HCV testing and treatment among HIV-infected PWID in St. Petersburg, Russia.

Methods: This study examined baseline data from the "Linking Infectious and Narcology Care" (LINC) and "Russia Alcohol Research Collaboration on HIV/AIDS" (Russia ARCH) studies. Participants included in this analysis were HIVinfected with a history of injection drug use. Descriptive statistics were performed to assess frequency of HCV testing and treatment.
\end{abstract}

Results: Participants ( $n=349$ [LINC], 207 [Russia ARCH]) had a mean age of 33.8 years (IQR: 31-37) in LINC and 33.0 (IQR: 30-36) in Russia ARCH; $26.6 \%$ (LINC) and $29.0 \%$ (Russia ARCH) were female; $100 \%$ were Caucasian. Nearly all participants had been tested for HCV (98.9\% in LINC, $97.1 \%$ in Russia ARCH). Almost all reported being diagnosed HCV positive (98.9\% in LINC, $97.1 \%$ in Russia ARCH). Only $2.3 \%$ of LINC and $5.0 \%$ of Russia ARCH participants reported ever receiving HCV treatment.

Conclusions: Among these cohorts of HIV-infected PWID in St. Petersburg, Russia, as of 2015 nearly all reported being tested for HCV and testing positive, while only $3.3 \%$ received any HCV treatment. In this new era of effective HCV pharmacotherapy, an enormous chasm in the HCV treatment cascade in Russia exists providing substantial opportunities for curing HCV in HIV-infected Russians with a history of injection drug use.

Trial registration: The studies described were registered with ClinicalTrials.gov through the National Institutes of Health: Linking Infectious and Narcology Care in Russia (LINC) - NCT01612455, registered 1 June 2012, first participant enrolled 3 July 2012; Alcohol's Impact on Inflammatory Markers in HIV Disease - Russia ARCH Cohort - NCT01614626, registered 25 May 2012, first participant enrolled 15 November 2012.

Keywords: HIV, HCV, PWID, Russia

\footnotetext{
* Correspondence: tsuij@uw.edu

${ }^{1}$ Department of Medicine, Section of General Internal Medicine, University of Washington School of Medicine and Harborview Hospital, 325 9th Ave, Box 359780, Seattle, WA 98104, USA

Full list of author information is available at the end of the article
} 


\section{Background}

Worldwide, hepatitis $\mathrm{C}$ virus (HCV) infection is estimated to affect 80 million people [1], placing them at risk for liver cirrhosis, hepatocellular carcinoma, and associated morbidity and mortality [2]. In most parts of the world, HCV transmission occurs through parenteral exposure, including via injection drug use (IDU) [3]. $\mathrm{HCV}$ is highly prevalent among people who inject drugs (PWID) through the sharing of contaminated injection paraphernalia [4].

Following the collapse of the former Soviet Union in the 1990s and the Afghan war, Russia experienced increased access to heroin and an upsurge in injection drug use among young adults along with subsequent risk for related viral infections [5]. Harm reduction programs exist in Russia, but are inadequate [6]. Access to needle exchange programs is limited and fear of law enforcement leads to reluctance to carry needles. Currently, opioid agonist treatments are illegal in Russia and thus unavailable for those persons with opioid use disorders $[7,8]$. As a result, the prevalence of HIV and HCV among Russian PWID is among the highest in the world. It is estimated that a quarter of PWID in Russia have $\mathrm{HIV}$ [9], while the vast majority have $\mathrm{HCV}$ [4]. A recent study of HCV prevalence in eight Russian cities reported that PWID in St. Petersburg had the highest prevalence of HCV (90 \%) [10]. Recent estimates of HCV prevalence in Russia suggest that $3-4 \%$ of the population is infected [1, 11-13].

With new, direct-acting $\mathrm{HCV}$ agents offering attainable sustained virologic response (SVR) or cure, understanding the HCV cascade of care is paramount. The $\mathrm{HCV}$ cascade of care describes successive steps of healthcare specific to $\mathrm{HCV}$ that result in optimal health outcomes. Areas of the $\mathrm{HCV}$ cascade of care include initial screening, confirmatory viral load testing, linkage to care, staging of disease, initiation of therapy, and receipt and adherence to therapy [14]. Deficits along the care continuum have been reported in numerous countries including the U.S., Canada, Australia, and India, particularly among PWID [15-19]. Less is known about gaps in other countries, including Russia, which has one of the largest populations of HIV-infected PWID [20].

Given the confluence of the ongoing Russian epidemic of $\mathrm{HCV}$ and HIV co-infection and the new effective HCV treatments, we investigated care for $\mathrm{HCV}$ among HIVinfected Russian PWID in St. Petersburg, Russia. Specifically, we evaluated the frequency of HCV screening and treatment, hypothesizing that screening would far exceed treatment in this population.

\section{Methods}

This analysis is a descriptive, observational study on self-reported HCV testing and treatment among HIV- infected Russian PWID. We analyzed data collected from two studies in St. Petersburg, Russia: LINC and Russia ARCH, for which study methods have been previously published [21, 22]. Linking Infectious and Narcology Care (LINC), is a randomized controlled trial testing a peer-led strengths-based case management intervention to link HIV-infected PWID hospitalized at a narcology (addiction) hospital to HIV medical care in St. Petersburg, Russia. Participants were recruited from inpatient wards at the City Addiction Hospital (CAH) in St. Petersburg, Russia from July 2012 through May 2014. Russia Alcohol Research Collaboration on HIV/AIDS (Russia ARCH) is an observational cohort that aims to evaluate the longitudinal association between alcohol consumption and biomarkers of microbial translocation and inflammation. Participants were recruited between November 2012 and June 2015 from clinical HIV and addiction sites, non-clinical sites and snowball sampling in St. Petersburg, Russia. Eligibility criteria for both studies included the following: 1) 18-70 years of age; 2) HIVinfection; 3) having two contacts to assist with followup; 4) living within $100 \mathrm{~km}$ of St. Petersburg and 5) having a telephone. For LINC, additional criteria included being hospitalized at the narcology hospital, history of injection drug use, and not currently being on antiretroviral therapy (ART) (prior history of ART was not an exclusion). For Russia ARCH being ARTnaïve (i.e. never having been on ART) was an eligibility criteria. All study participants provided informed consent and Institutional Review Boards of Boston University Medical Campus and First St. Petersburg Pavlov State Medical University approved the LINC and Russia ARCH studies.

For this analysis, the Russia ARCH sample was limited to participants who were not previously enrolled in the LINC study and who were categorized as PWID (i.e., participant reported at least one of the following: used needles to inject drugs prior to HIV diagnosis or past 30-day IDU). Using responses from the baseline questionnaire, we assessed the following: previous testing of $\mathrm{HCV}$ [23], location of $\mathrm{HCV}$ testing [23], date of HCV testing [23], physician reported $\mathrm{HCV}$ status [23], prior treatment for $\mathrm{HCV}$ [23], and date of HCV treatment initiation [23], demographics, HIV risk behaviors [24] and substance use [24-29]. Questions about HCV testing were worded in the following manner: "Have you ever been tested for the hepatitis C virus?", and "Has a doctor ever told you that you had the hepatitis $C$ virus?" As such, questions did not refer to the specific diagnostic test done (i.e. screening antibody or $\mathrm{HCV}$ viral load). Not all questions were asked in both surveys. 


\section{Results}

The total sample included 556 HIV-infected Russian adult PWID ( $n=349$ [LINC], 207 [Russia ARCH]). Details of enrollment are presented in Additional file 1: Figure S1 and Additional file 2: Figure S2. In LINC 382 potential participants were assessed, and of those, 349 were found to be eligible and were enrolled and included in the analysis. In Russia ARCH 556 persons were assessed, and of those 365 were found to be eligible and 364 were enrolled. Of those, 90 were also participants in LINC, 13 subsequently disenrolled from the study, and 54 were not known to be injection drug users, and were therefore excluded from this analysis, leaving 207 in the sample. Only $1 \%$ of persons screened for LINC were excluded for current ART use, and $13 \%$ of Russia ARCH persons screened were excluded for past or current ART.

Baseline demographic and other characteristics of each sample, and both samples combined, are shown in Table 1. Participants in these two studies were relatively young, the majority were men, and as is expected for this population, all were Caucasian. The vast majority completed secondary education, and approximately half reported being unemployed. Median time since HIV diagnosis was 7.1 years (IQR $=4-12$ ), and median CD4 cell count was 349 (IQR = 201-550). All in Russia ARCH and the vast majority in LINC were HIV ART-naïve. Current substance use disorders were common in both cohorts (Table 1).

Almost all HIV-infected PWID in LINC (345 [98.9\%]) and Russia ARCH (201 [97.1\%]) reported past HCV testing; similarly nearly all participants in LINC (345 [98.9 \%]) and Russia ARCH (201 [97.1\%]) reported past physician diagnosis of $\mathrm{HCV}$. In most cases (328 [95.1\%]), the time since $\mathrm{HCV}$ diagnosis was $\geq 12$ months in LINC. Of 345 reporting HCV testing in LINC, testing occurred in hospitals (193 [55.9\%]), outpatient clinics (107 [31.0\%]), and prisons (37 [10.7\%]) (Table 2). Almost all were $\mathrm{HCV}$ treatment-naïve in both LINC (336 [97.4 \%]) and Russia ARCH (191 [95.0\%]) (Table 3).

Among eight reporting prior HCV treatment in LINC, $7(87.5 \%)$ initiated treatment $\geq 12$ months prior. Of 10 with prior HCV treatment in Russia ARCH, 5 (50.0 \%) reported achieving SVR and 3 (30.0\%) had unknown outcomes (Table 3). The median age of the 8 HIV-HCV co-infected PWID in LINC receiving $\mathrm{HCV}$ treatment was 32.6 (IQR 31.15-34.4), 5 (62.5\%) were never married, all 8 (100\%) were male, 1 (12.5\%) was working part-time, and 5 (62.5\%) completed secondary education or lower. Among ten Russia ARCH participants who reported receiving $\mathrm{HCV}$ treatment, the median age was 31.5 (IQR 29-35), 4 (40 \%) were married or living with a partner, 6 (60\%) were male, 3 (30\%) were working part- time or full-time, and 9 (90\%) completed secondary education or lower.

\section{Discussion}

This study of two St. Petersburg Russian cohorts of HIV-infected PWID found an enormous gap between testing and receipt of $\mathrm{HCV}$ treatment, revealing a "chasm" in the hepatitis C virus ( $\mathrm{HCV})$ care cascade. This study found that nearly all participants reported being screened and informed that they had been $\mathrm{HCV}$ infected, suggesting that screening efforts are robust in this population of PWID with HIV. In contrast to nearly ubiquitous rates of screening, few patients $(\mathrm{LINC}=$ $2.3 \%$, Russia $\mathrm{ARCH}=5.0 \%$ ) reported ever receiving treatment. This points to a chasm with regard to not meeting European Association for the Study of the Liver (EASL) guidelines for prioritizing $\mathrm{HCV}$ treatment for PWID [30] and recommendations set forth by Grebely et al. [31]. Based on these results it appears that there is a substantial opportunity to improve care, and corresponding health outcomes, among $\mathrm{HIV} / \mathrm{HCV}$ co-infected PWID in Russia.

The finding that $\mathrm{HCV}$ infection was nearly universal among these HIV-infected PWID in St. Petersburg is consistent with prior literature. Globally, Russia has among the highest burdens of HCV co-infection among PWID with HIV [32]. The HIV epidemic in Russia is primarily driven through parenteral drug use, and in this context, the prevalence of $\mathrm{HCV}$ infection, which almost invariably precedes infection with HIV, will be extremely high to omnipresent [33]. Indeed, modeling studies suggest that in countries where HIV is driven by injecting behavior, the prevalence of $\mathrm{HCV}$ can be used as a measure of HIV risk [34], and Russia has a high prevalence of HCV among PWID (50-90 \%) $[4,10]$. Therefore, it is not surprising that nearly all (97-99 \%) of these HIVinfected PWID reported being told that they had HCV. However, it is unlikely that in all cases the diagnosis was confirmed with HCV RNA testing. Due to cost constraints, and the fact that patients frequently have to pay out of pocket for these tests, HCV RNA and genotype testing are uncommonly performed in Russia [35]. Given that approximately $25 \%$ of $\mathrm{HCV}$-infected people will spontaneously clear their infection [36], the true prevalence of current $\mathrm{HCV}$ infection, rather than past infection with $\mathrm{HCV}$, in this sample was likely lower than reported.

This study demonstrates a large discrepancy between rates of testing and treatment among this population of HIV-infected PWID, many of whom were being treated for their opioid use disorders, which may explain their high testing rates. It appears that efforts to test these high risk patients for $\mathrm{HCV}$ infection are successful and thorough. However, despite these high rates of $\mathrm{HCV}$ 
Table 1 Baseline demographic characteristics of HIV-infected Russian PWID in LINC $(n=349)$ and Russia ARCH $(n=207)$

\begin{tabular}{|c|c|c|c|c|c|c|}
\hline \multirow[b]{2}{*}{ Characteristic } & \multicolumn{2}{|l|}{ LINC } & \multicolumn{2}{|c|}{ Russia ARCH } & \multicolumn{2}{|c|}{ Total } \\
\hline & No. & $(\%)$ & No. & (\%) & No. & (\%) \\
\hline Median Age (IQR) & \multicolumn{2}{|c|}{$33.8(31-37)$} & \multicolumn{2}{|c|}{$33.0(30-36)$} & \multicolumn{2}{|c|}{$33.5(31-37)$} \\
\hline \multicolumn{7}{|l|}{ Sex } \\
\hline Male & 256 & 73.4 & 147 & 71.0 & 403 & 72.5 \\
\hline Female & 93 & 26.6 & 60 & 29.0 & 153 & 27.5 \\
\hline \multicolumn{7}{|l|}{ Race } \\
\hline Caucasian & 349 & 100 & 207 & 100 & 556 & 100 \\
\hline Other & 0 & 0 & 0 & 0 & 0 & 0 \\
\hline \multicolumn{7}{|l|}{ Education } \\
\hline Secondary Education or lower & 314 & 90.0 & 179 & 86.5 & 493 & 88.7 \\
\hline Higher education & 35 & 10.0 & 28 & 13.5 & 63 & 11.3 \\
\hline \multicolumn{7}{|l|}{ Marital Status } \\
\hline Married or living with partner & 105 & 30.1 & 96 & 46.4 & 201 & 36.2 \\
\hline Other & 244 & 69.9 & 111 & 53.6 & 355 & 63.8 \\
\hline \multicolumn{7}{|l|}{ Employment } \\
\hline Full-time & 83 & 23.8 & 69 & 33.3 & 152 & 27.3 \\
\hline Part-time & 41 & 11.7 & 22 & 10.6 & 63 & 11.3 \\
\hline Disability & 11 & 3.2 & 3 & 1.4 & 14 & 2.5 \\
\hline Unemployed & 190 & 54.4 & 106 & 51.2 & 296 & 53.2 \\
\hline Other (includes retired, homemaker) & 24 & 6.9 & 7 & 3.4 & 31 & 5.6 \\
\hline Median Monthly Income (IQR) & \multicolumn{2}{|c|}{$35000(20000-50000)$} & \multicolumn{2}{|c|}{$15000(5000-30000)$} & \multicolumn{2}{|c|}{$28000(10000-40000)$} \\
\hline Median Years Since HIV Diagnosis (IQR) & \multicolumn{2}{|c|}{$6.6(4-12)$} & \multicolumn{2}{|c|}{$7.4(4-12)$} & \multicolumn{2}{|c|}{$7.1(4-12)$} \\
\hline Median CD4 Cell Count (IQR) & \multicolumn{2}{|c|}{$\begin{array}{l}n=329 \\
311(163-492)\end{array}$} & \multicolumn{2}{|c|}{$\begin{array}{l}n=143 \\
448(294-639)\end{array}$} & \multicolumn{2}{|c|}{$\begin{array}{l}N=472 \\
349(201-550)\end{array}$} \\
\hline \multicolumn{7}{|l|}{ ART (current or past) } \\
\hline Yes & 43 & 12.3 & 0 & 0 & 43 & 7.7 \\
\hline No & 306 & 87.7 & 207 & 100 & 513 & 92.3 \\
\hline Past 12-month drug dependence & \multicolumn{6}{|c|}{$n=344$} \\
\hline Yes & 326 & 94.8 & 127 & 61.4 & 453 & 82.2 \\
\hline No & 18 & 5.2 & 80 & 38.6 & 98 & 17.8 \\
\hline Past 30-day injection drug use & \multicolumn{6}{|c|}{$n=198^{\mathrm{a}}$} \\
\hline Yes & 183 & 92.4 & 94 & 45.4 & 277 & 68.4 \\
\hline No & 15 & 7.6 & 113 & 54.6 & 128 & 31.6 \\
\hline \multicolumn{7}{|l|}{ Past 12-month alcohol dependence } \\
\hline Yes & & & 138 & 67.0 & & \\
\hline No & & & 68 & 33.0 & & \\
\hline
\end{tabular}

Abbreviations: $H C V$ hepatitis $C$ virus, $H I V$ human immunodeficiency virus, $P W I D$ people who inject drugs, $A R T$ antiretroviral treatment, IQR interquartile range

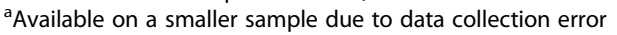

testing, it appears that only a very small fraction $(3.3 \%)$ of these HIV-infected PWID can access treatment. In contrast, another study not focused on HIV-infected persons reported lower rates of HCV diagnosis in Russia (40\%), but also low rates of treatment $(<0.1 \%)$ [11]. Similarly, in other countries, such as the U.S., Canada, Australia, and India, it appears that HCV testing efforts often fall short, with many persons, including PWID, being unaware of their infection [17-19, 37-40]. The estimated proportion of persons treated for $\mathrm{HCV}$ in the U.S. is also low, $9 \%$ reported in a recent meta-analysis [15], and HIV/HCV co-infected are often not referred for treatment [41]. It may be worth questioning the rationale for such an aggressive HCV testing program, given the limited effort to provide $\mathrm{HCV}$ treatment. The potential that awareness of $\mathrm{HCV}$ diagnosis positively 
Table 2 HCV testing among HIV-infected Russian PWID in LINC $(n=349)$ and Russia ARCH $(n=207)$

\begin{tabular}{|c|c|c|c|c|c|c|}
\hline \multirow[b]{2}{*}{ Category } & \multicolumn{2}{|l|}{ LINC } & \multicolumn{2}{|c|}{ Russia ARCH } & \multicolumn{2}{|c|}{ Total } \\
\hline & No. & $(\%)$ & No. & $(\%)$ & No. & $(\%)$ \\
\hline \multicolumn{7}{|l|}{ HCV testing } \\
\hline Yes & 345 & 98.9 & 201 & 97.1 & 546 & 98.2 \\
\hline No & 2 & 0.6 & 3 & 1.4 & 5 & 0.9 \\
\hline Unknown & 2 & 0.6 & 3 & 1.4 & 5 & 0.9 \\
\hline \multicolumn{7}{|c|}{ HCV Diagnosis (Physician Notified) } \\
\hline Yes & 345 & 98.9 & 201 & 97.1 & 546 & 98.2 \\
\hline No & 4 & 1.1 & 5 & 2.4 & 9 & 1.6 \\
\hline Unknown & 0 & 0 & 1 & 0.5 & 1 & 0.2 \\
\hline Time since HCV diagnosis & $n=345$ & & & & & \\
\hline$\leq 6$ months & 6 & 1.7 & & & & \\
\hline 6-12 months & 11 & 3.2 & & & & \\
\hline$\geq 12$ months & 328 & 95.1 & & & & \\
\hline Location of HCV testing & $n=345$ & & & & & \\
\hline Prison & 37 & 10.7 & & & & \\
\hline Outpatient clinic & 107 & 31.0 & & & & \\
\hline Hospital inpatient & 193 & 55.9 & & & & \\
\hline Needle exchange program & 1 & 0.3 & & & & \\
\hline Drug treatment program & 6 & 3.4 & & & & \\
\hline Family planning & 2 & 0.6 & & & & \\
\hline Other & 2 & 0.6 & & & & \\
\hline
\end{tabular}

Abbreviations: $H C V$ hepatitis $C$ virus, HIV human immunodeficiency virus, $P W I D$ people who inject drugs

Table 3 HCV Treatment among HCV/HIV-co-infected Russian PWID in LINC $(n=345)$ and Russia ARCH $(n=201)$

\begin{tabular}{|c|c|c|c|c|c|c|}
\hline \multirow[b]{2}{*}{ Category } & \multicolumn{2}{|l|}{ LINC } & \multicolumn{2}{|c|}{ Russia ARCH } & \multicolumn{2}{|c|}{ Total } \\
\hline & $\overline{\text { No. }}$ & $\overline{(\%)}$ & $\overline{\text { No. }}$ & (\%) & $\overline{\text { No. }}$ & (\%) \\
\hline \multicolumn{7}{|l|}{ HCV treatment status } \\
\hline Current HCV treatment & 3 & 0.9 & 1 & 0.5 & 4 & 0.7 \\
\hline Past HCV treatment & 5 & 1.4 & 9 & 4.5 & 14 & 2.6 \\
\hline Never treated & 336 & 97.4 & 191 & 95.0 & 527 & 96.5 \\
\hline Refused to answer & 1 & 0.3 & 0 & 0.0 & 1 & 0.2 \\
\hline Time of HCV treatment initiation & $n=8$ & & & & & \\
\hline$\leq 6$ months & 1 & 12.5 & & & & \\
\hline$\geq 12$ months & 7 & 87.5 & & & & \\
\hline Was SVR achieved & & & \multicolumn{2}{|l|}{$n=10$} & & \\
\hline Yes & & & 5 & 50.0 & & \\
\hline No & & & 2 & 20.0 & & \\
\hline Don't know & & & 3 & 30.0 & & \\
\hline
\end{tabular}

Abbreviations: $H C V$ hepatitis $C$ virus, HIV human immunodeficiency virus, PWID people who inject drugs, SVR sustained virologic response impacts an individual's risk behaviors is another rationale for testing; however the evidence for this impact is mixed [38, 42, 43].

A limitation of this study is that HCV status was based on self-report. Also, we did not specify the nature of prior $\mathrm{HCV}$ testing in the questionnaire, nor ask about confirmatory viral load or genotype testing. Given the expense of confirmatory $\mathrm{HCV}$ viral load testing, it is likely that most participants only had an antibody test. Another limitation is that this study is based on secondary analysis of existing data from two other studies, which included eligibility criteria that participants could not be on ART. Therefore, the sample may not be fully representative of all co-infected PWID in St. Petersburg. The sample might potentially be biased toward patients who are difficult to link to care. However, there were relatively small numbers of participants who were ineligible because of ART use: in LINC $1 \%$, and in Russia $\mathrm{ARCH} 13 \%$. It is likely the sample may be potentially biased toward younger, newly diagnosed HIV-infected PWID with higher CD4 cell counts not meeting criteria for treatment. Russian guidelines at the time of study stated that ART should be initiated for any patients with CD4 cell counts below 350 cells $/ \mathrm{mm}^{3}$. At baseline, approximately half of the participants in the combined sample had baseline counts below that threshold, and over time we have observed that nearly one quarter of the sample has initiated ART. Another limitation is that we did not ask participants about specific treatments received; therefore, we cannot be sure that the few patients who reported being treated had actually received standard treatment (as opposed to vitamins or other supplements). However, the exact wording of the question ("Have you taken medication to treat hepatitis C, like Interferon and Ribavirin?") implied anti-HCV treatment that was the standard at the time.

This study was conducted largely before the arrival of direct-acting antiviral (DAA) therapies, when interferon based therapies were used. Of concern is that countries like Russia, which are transitioning from the classification of middle to high income (and thus restricted from generic medications), may be particularly challenged to afford new therapies for HCV. However, the study result speaks to a great need for treatment among co-infected PWID in Russia, particularly given the challenge of meeting WHO's targets for the goal of "elimination of viral hepatitis as a major public health threat by 2030 " [44]. Given that persons who are co-infected with HIV/ $\mathrm{HCV}$ are at greater risk for having progression of their HCV-related liver disease to cirrhosis and hepatocellular carcinoma, the need is more urgent to address treatment in this population in order to mitigate morbidity and avoid downstream costs [45-47]. Furthermore, treatment of $\mathrm{HCV}$ in this PWID population holds the 
potential to prevent $\mathrm{HCV}$ transmission ("treatment as prevention") [47-49]. Study results also indicate a need for expanded ART as an important initial step in engagement of care.

\section{Conclusion}

Among HIV-infected PWID in St. Petersburg, Russia, nearly all persons reported having been tested and found to have been infected with $\mathrm{HCV}$, yet few $(3.3 \%)$ had ever been treated for their HCV infection. As such, the treatment chasm in the Russian HCV cascade of care among these HIV-infected PWID points to the great need for expanded $\mathrm{HCV}$ treatment in this population.

\section{Additional files}

Additional file 1: Figure S1. LINC Enrollment. (PDF $230 \mathrm{~kb}$ )

Additional file 2: Figure S2. Russia ARCH Enrollment. (PDF $285 \mathrm{~kb}$ )

\section{Abbreviations}

ART: Antiretroviral therapy; CAH: City Addiction Hospital; DAA: Direct-acting antiviral; HCV: Hepatitis c virus; HIV: Human immunodeficiency virus; IDU: Injection drug use; IQR: Interquartile range; LINC: Linking Infectious and Narcology Care; PWID: People Who Inject Drugs; Russia ARCH: Russia Alcohol Research Collaboration on HIV/AIDS; SVR: Sustained virologic response

\section{Acknowledgements}

The project described was supported by grants R01DA032082 from the National Institute on Drug Abuse, U01AA020780, U01AA021989, U24AA020778, and U24AA020779 from the National Institute on Alcohol Abuse and Alcoholism. The authors wish to thank Sally Bendiks for her help in the submission, as well as the study participants for their contributions to research.

\section{Funding}

The project described was supported by grants R01DA032082 from the National Institute on Drug Abuse, U01AA020780, U01AA021989, U24AA020778, and U24AA020779 from the National Institute on Alcohol Abuse and Alcoholism. The content is solely the responsibility of the authors and does not necessarily represent the official views of the National Institute on Drug Abuse, National Institute on Alcohol Abuse and Alcoholism or the National Institutes of Health.

\section{Availability of data and materials}

The datasets supporting the conclusions of this article are included within the article.

\begin{abstract}
Authors' contributions
JIT and SCK conceived the study question, led the analytic planning and wrote the first draft of the manuscript. EK led the Russian team and was the principal investigator in Russia. DL was the infectionist and co-investigator on the study. CEC provided data management and conducted the analyses. NG was the project manager in the United States. JHS was the principal investigator of the parent study. All authors contributed to developing the analytic plan, reviewed, revised, and approved the submitted manuscript.
\end{abstract}

\section{Competing interests}

The authors declare that they have no competing interests.

\section{Consent for publication}

Not applicable.

\section{Ethics approval and consent to participate}

All study participants provided informed consent and Institutional Review Boards of Boston University Medical Campus and First St. Petersburg Pavlov State Medical University approved the LINC and Russia ARCH studies.

\section{Author details}

Department of Medicine, Section of General Internal Medicine, University of Washington School of Medicine and Harborview Hospital, 325 9th Ave, Box 359780, Seattle, WA 98104, USA. ${ }^{2}$ Department of Global Health, Boston University School of Public Health, 801 Massachusetts Avenue, 3nd Floor, Boston, MA 02118, USA. ${ }^{3}$ St. Petersburg Bekhterev Research

Psychoneurological Institute, Bekhtereva St., 3, St. Petersburg 192019, Russian Federation. ${ }^{4}$ First St. Petersburg Pavlov State Medical University, Lev Tolstoy St. 6/8, St. Petersburg 197022, Russian Federation. ${ }^{5}$ Pasteur Research Institute of Epidemiology and Microbiology, St. Petersburg, Russian Federation, Mira St. 14, St. Petersburg 197101, Russian Federation. ${ }^{6}$ Data Coordinating Center, Boston University School of Public Health, 85 East Newton Street, 9th Floor, Boston, MA 02118, USA. 'Department of Medicine, Section of General Internal Medicine, Clinical Addiction Research and Education Unit, Boston Medical Center, 801 Massachusetts Avenue, 2nd Floor, Boston, MA 02118, USA. ${ }^{8}$ Department of Medicine, Section of General Internal Medicine, Clinical Addiction Research and Education Unit, Boston University School of Medicine/Boston Medical Center, 801 Massachusetts Avenue, 2nd Floor, Boston, MA 02118, USA. 'Department of Community Health Sciences, Boston University School of Public Health, 801 Massachusetts Avenue, 2nd Floor, Boston, MA 02118, USA.

Received: 3 May 2016 Accepted: 28 September 2016

Published online: 11 October 2016

\section{References}

1. Gower E, Estes C, Blach S, Razavi-Shearer K, Razavi H. Global epidemiology and genotype distribution of the hepatitis C virus infection. J Hepatol. 2014; 61:545-57.

2. Di Bisceglie AM. Natural history of hepatitis C: its impact on clinical management. Hepatology. 2000;31:1014-8.

3. Alter MJ. Epidemiology of hepatitis C virus infection. World J Gastroenterol. 2007;13:2436-41.

4. Nelson PK, Mathers BM, Cowie B, Hagan H, Des JD, Horyniak D, et al. Global epidemiology of hepatitis $B$ and hepatitis $C$ in people who inject drugs: results of systematic reviews. Lancet. 2011;378:571-83.

5. Kalichman SC, Kelly JA, Sikkema KJ, Koslov AP, Shaboltas A, Granskaya J. The emerging AIDS crisis in Russia: review of enabling factors and prevention needs. Int J STD AIDS. 2000;11:71-5.

6. Samet JH. Russia and human immunodeficiency virus-beyond crime and punishment. Addiction. 2011;106:1883-5.

7. Sarang A, Rhodes T, Platt L. Access to syringes in three Russian cities: implications for syringe distribution and coverage. Int J Drug Policy. 2008;19 Suppl 1:S25-36.

8. Krupitsky E, Zvartau E, Woody G. Use of naltrexone to treat opioid addiction in a country in which methadone and buprenorphine are not available. Curr Psychiatry Rep. 2010;12:448-53.

9. Jolley E, Rhodes T, Platt L, Hope V, Latypov A, Donoghoe M, et al. HIV among people who inject drugs in Central and Eastern Europe and Central Asia: a systematic review with implications for policy. BMJ Open. 2012;2: e001465.

10. Heimer R, Eritsyan $K$, Barbour R, Levina OS. Hepatitis C virus seroprevalence among people who inject drugs and factors associated with infection in eight Russian cities. BMC Infect Dis. 2014;14 Suppl 6:S12.

11. Wedemeyer H, Dore GJ, Ward JW. Estimates on HCV disease burden worldwide - filling the gaps. J Viral Hepat. 2015;22 Suppl 1:1-5.

12. Pimenov N, Chulanov V, Komarova S, Karandashova I, Neverov A. Hepatitis $C$ in Russia: current epidemiology and approaches to improving diagnosis and surveillance. Epidemiol Infect Dis. 2012:4:4-10.

13. Mukomolov S, Trifonova G, Levakova I, Bolsun D, Krivanogova E. Hepatitis C in the Russian Federation: challenges and future directions. Hepat Med. 2016;8:51-60

14. Linas BP, Barter DM, Leff JA, Assoumou SA, Salomon JA, Weinstein MC, et al. The hepatitis C cascade of care: identifying priorities to improve clinical outcomes. PLoS One. 2014;9:e97317.

15. Yehia BR, Schranz AJ, Umscheid CA, Lo Re 3rd V. The treatment cascade for chronic hepatitis C virus infection in the United States: a systematic review and meta-analysis. PLoS One. 2014;9:e101554.

16. Mehta SH, Genberg BL, Astemborski J, Kavasery R, Kirk GD, Vlahov D, et al. Limited uptake of hepatitis $C$ treatment among injection drug users. J Community Health. 2008;33:126-33. 
17. Socias ME, Shannon K, Montaner JS, Guillemi S, Dobrer S, Nguyen P, et al. Gaps in the hepatitis $C$ continuum of care among sex workers in Vancouver, British Columbia: Implications for voluntary hepatitis C virus testing, treatment and care. Can J Gastroenterol Hepatol. 2015;29:411-6.

18. Hajarizadeh B, Grebely J, McManus H, Estes C., Razavi H, Gray RT, et al. Chronic hepatitis $\mathrm{C}$ burden and care cascade in Australia in the era of interferon-based treatment. J Gastroenterol Hepatol. 2016. doi:10.1111/jgh. 13453

19. Solomon SS, Mehta SH, Srikrishnan AK, Solomon S, McFall AM, Laeyendecker $\mathrm{O}$, et al. Burden of hepatitis $\mathrm{C}$ virus disease and access to hepatitis C virus services in people who inject drugs in India: a crosssectional study. Lancet Infect Dis. 2015;15:36-45.

20. Mathers BM, Degenhardt L, Phillips B, Wiessing L, Hickman M, Strathdee SA, et al. Global epidemiology of injecting drug use and HIV among people who inject drugs: a systematic review. Lancet. 2008;372:1733-45.

21. Gnatienko N, Han SC, Krupitsky E, Blokhina E, Bridden C, Chaisson CE, et al. Linking Infectious and Narcology Care (LINC) in Russia: design, intervention and implementation protocol. Addict Sci Clin Pract. 2016;11:10.

22. So-Armah KA, Edelman EJ, Cheng DM, Doyle MF, Patts GJ, Gnatienko N, et al. Effects of heavy drinking on T-cell phenotypes consistent with immunosenescence in untreated HIV infection. Alcohol Clin Exp Res. 2016; 40:1737-43.

23. National Institute on Drug Abuse: Seek, Test, Treat and Retain Initiative. HIV/ HCV/STI testing status and organizational testing practices questionnaire. 2013. Available at: http://www.drugabuse.gov/researchers/researchresources/data-harmonization-projects/seek-test-treat-retain/addressing-hivamong-vulnerable-populations (accessed 06 Oct 2015).

24. Needle R, Fisher DG, Weatherby N, Chitwood D, Brown B, Cesari H, et al. Reliability of self-reported HIV risk behaviors of drug users. Psychol Addict Behav. 1995;9:242-50.

25. Sheehan DV, Lecrubier $Y$, Sheehan KH, Amorim P, Janavs J, Weiller E, et al. The Mini-International Neuropsychiatric Interview (M.I.N.I.): the development and validation of a structured diagnostic psychiatric interview for DSM-IV and ICD-10. J Clin Psychiatry. 1998;59 Suppl 20:22-33.

26. Weatherby N, Needle R, Cesar H, Booth R, McCoy C, Watters J, et al. Validity of self-reported drug use among injection drug users and crack smokers recruited through street outreach. Eval Program Plann. 1994;17:347-55.

27. McLellan AT, Luborsky L, Cacciola J, Griffith J, Evans F, Barr HL, et al. New data from the Addiction Severity Index. Reliability and validity in three centers. J Nerv Ment Dis. 1985;173:412-23.

28. Broome K, Knight K, Joe G, Simpson D. Evaluating the drug-abusing probationer: clinical interview versus self-administered assessment. Crim Justice Behav. 1996;23:593-606

29. Knight K, Simpson D, Morey J. Evaluation of the TCU Drug Screen. National Criminal Justice Reference Service. 2002. Report No.: 196682.

30. European Association for Study of Liver. EASL recommendations on treatment of hepatitis C 2015. J Hepatol. 2015;63:199-236.

31. Grebely J, Robaeys G, Bruggmann P, Aghemo A, Backmund M, Bruneau J, et al. Recommendations for the management of hepatitis $C$ virus infection among people who inject drugs. Int J Drug Policy. 2015;26:1028-38.

32. Platt L, Easterbrook P, Gower E, McDonald B, Sabin K, McGowan C, et al. Prevalence and burden of HCV co-infection in people living with HIV: a global systematic review and meta-analysis. Lancet Infect Dis. 2016;16:797-808.

33. Thomas DL, Leoutsakas D, Zabransky T, Kumar MS. Hepatitis C in HIVinfected individuals: cure and control, right now. J Int AIDS Soc. 2011;14:22.

34. Vickerman P, Hickman M, May M, Kretzschmar M, Wiessing L. Can hepatitis $C$ virus prevalence be used as a measure of injection-related human immunodeficiency virus risk in populations of injecting drug users? An ecological analysis. Addiction. 2010;105:311-8.

35. Ocheret D, Bikmukhametov D, Sultangaziev A, Matuizaite E. Current situation regarding access to hepatitis $C$ treatment in Eastern Europe and Central Asia. Eurasian Harm Reduction Network (EHRN). 2013. Available at: https://www.harm-reduction.org/library/current-situation-regarding-accesshepatitis-c-treatment-eastern-europe-and-central-asia-0. Archived by WebCite $^{\oplus}$ at http://www.webcitation.org/6c5CV08LL. (Accessed 6 Oct 2015).

36. Denniston MM, Jiles RB, Drobeniuc J, Klevens RM, Ward JW, McQuillan GM, et al. Chronic hepatitis C virus infection in the United States, National Health and Nutrition Examination Survey 2003 to 2010. Ann Intern Med. 2014;160:293-300.

37. Denniston MM, Klevens RM, McQuillan GM, Jiles RB. Awareness of infection, knowledge of hepatitis $C$, and medical follow-up among individuals testing positive for hepatitis C: National Health and Nutrition Examination Survey 2001-2008. Hepatology. 2012;55:1652-61.

38. Kwiatkowski CF, Fortuin CK, Booth RE. The association between knowledge of hepatitis $C$ virus status and risk behaviors in injection drug users. Addiction. 2002;97:1289-94.

39. Bouscaillou J, Champagnat J, Luhmann N, Avril E, Inaridze I, Miollany V, et al. Hepatitis C among people who inject drugs in Tbilisi, Georgia: an urgent need for prevention and treatment. Int J Drug Policy. 2014;25:871-8.

40. Bowring AL, Luhmann N, Pont S, Debaulieu C, Derozier S, Asouab F, et al. An urgent need to scale-up injecting drug harm reduction services in Tanzania: prevalence of blood-borne viruses among drug users in Temeke District, Dar-es-Salaam, 2011. Int J Drug Policy. 2013;24:78-81.

41. Cachay ER, Hill L, Wyles D, Colwell B, Ballard C, Torriani F, et al. The hepatitis C cascade of care among HIV infected patients: a call to address ongoing barriers to care. PLoS One. 2014;9:e102883.

42. Tsui Jl, Saitz R, Cheng DM, Nunes D, Libman H, Alperen JK, et al. Awareness of hepatitis $C$ diagnosis is associated with less alcohol use among persons co-infected with HIV. J Gen Intern Med. 2007;22:822-5.

43. Tsui Jl, Vittinghoff E, Hahn JA, Evans JL, Davidson PJ, Page K. Risk behaviors after hepatitis $C$ virus seroconversion in young injection drug users in San Francisco. Drug Alcohol Depend. 2009;105:160-3.

44. World Health Organization. Draft global health sector strategies: viral hepatitis, 2016-2021. 2016. Report No.: A69/32.

45. Kirk GD, Mehta SH, Astemborski J, Galai N, Washington J, Higgins Y, et al. $H I V$, age, and the severity of hepatitis C virus-related liver disease: a cohort study. Ann Intern Med. 2013;158:658-66.

46. Weber R, Sabin CA, Friis-Moller N, Reiss P, El-Sadr WM, Kirk O, et al. Liverrelated deaths in persons infected with the human immunodeficiency virus: the D:A:D study. Arch Intern Med. 2006;166:1632-41.

47. de Ledinghen V, Barreiro P, Foucher J, Labarga P, Castera L, Vispo ME, et al. Liver fibrosis on account of chronic hepatitis $C$ is more severe in HIVpositive than HIV-negative patients despite antiretroviral therapy. J Viral Hepat. 2008;15:427-33.

48. Martin NK, Vickerman P, Grebely J, Hellard M, Hutchinson SJ, Lima VD, et al. Hepatitis C virus treatment for prevention among people who inject drugs: modeling treatment scale-up in the age of direct-acting antivirals. Hepatology. 2013;58:1598-609.

49. Grebely J, Matthews GV, Lloyd AR, Dore GJ. Elimination of hepatitis C virus infection among people who inject drugs through treatment as prevention: feasibility and future requirements. Clin Infect Dis. 2013;57:1014-20.

\section{Submit your next manuscript to BioMed Central and we will help you at every step:}

- We accept pre-submission inquiries

- Our selector tool helps you to find the most relevant journal

- We provide round the clock customer support

- Convenient online submission

- Thorough peer review

- Inclusion in PubMed and all major indexing services

- Maximum visibility for your research

Submit your manuscript at www.biomedcentral.com/submit
) Biomed Central 